\title{
Penguatan Pendidikan Karakter pada Masa New Normal Covid-19 melalui Flipped Classroom
}

\author{
An-Nisa Apriani*, Intan Kurniasari Suwandi, Yusinta Dwi Ariyani, Indah Perdana Sari \\ Department of Primary Teacher Education, Alma Ata University \\ Jl. Brawijaya No. 99 Yogyakarta 55183 \\ *Corresponding Author. e-mail: annisa.apriani@almaata.ac.id
}

\begin{abstract}
Abstrak
Penelitian ini bertujuan untuk mendeskripsikan tentang peran flipped classroom dalam penguatan karakter siswa sekolah dasar pada masa new normal Covid-19. Metode yang digunakan dalam penelitian ini yaitu penelitian studi kepustakaan. Data dalam penelitian ini merupakan data sekunder berupa buku-buku ilmiah, jurnal ilmiah, dan laporan penelitian. Teknik analisis data dalam penelitian meliputi tiga tahapan: organize, synthesize, dan identify. Hasil penelitian ini menunjukkan bahwa flipped classroom memiliki relevansi yang kuat dalam penguatan pendidikan karakter siswa pada masa new normal Covid-19. Aktivitas dalam flipped classroom meliputi kegiatan tatap muka dan pembelajaran online yang berfokus pada proses pembelajaran yang berpusat pada siswa. Aktivitas pembelajaran tersebut memberikan kesempatan pada siswa sekolah dasar secara lebih luas untuk mengembangkan nilai-nilai moral yang dimilikinya. Pendekatan ini juga mendukung siswa dalam membangun pengetahuan baru, belajar secara efektif dan efesien, dan memperkuat karakter siswa. Pembelajaran melalui flipped classroom mendukung tercapainya tujuan program Penguatan Pendidikan Karakter (PPK) pada masa new normal Covid-19. Salah satu nilai utama PPK yang dapat meningkat dan berkembang melalui pendekatan flipped classroom yaitu nilai kemandirian.
\end{abstract}

Kata Kunci: penguatan pendidikan karakter, masa new normal Covid-19, Flipped Classroom

\section{Strengthening Character Education in New Normal Covid-19 Periode through Flipped Classroom}

\begin{abstract}
This study aims to describe the role of flipped classrooms in strengthening the character of elementary school students during the new normal covid-19 period. The method used in this research is library research. The data in this research is secondary data in the form of scientific books, scientific journals, and research reports. The data analysis technique in this research includes three stages: organize, synthesize, and identify. The results of this study indicate that the flipped classroom has strong relevance in strengthening the character education of students during the new normal Covid-19 period. Activities in the flipped classroom include face-to-face activities and online learning that focus on student-centered learning processes. These learning activities provide opportunities for elementary school students to a wider extent to develop their moral values. This approach also supports students in building new knowledge, learning effectively and efficiently, and strengthening student character. Learning through flipped classrooms supports the achievement of the objectives of the Penguatan Pendidikan Karakter's program (PPK) during the new normal Covid-19 period. One of the main values of PPK's program that can improve and develop through the flipped classroom approach is the value of independence.
\end{abstract}

Keywords: strengthening character education, new normal Covid-19 periode, Flipped Classroom

How to Cite: Apriani, A., Suwandi, I. K., Ariyani, Y. D. \& Sari, I. P. (2021). Penguatan pendidikan karakter pada masa new normal covid-19 melalui flipped classroom. Jurnal Penelitian Ilmu Pendidikan, 14(2), 102-113. doi: https://doi.org/10.21831/jpipfip.v14i1.37909.

Received 16-01-2021; Received in revised from 09-02-2021; Accepted 17-07-2021

This is an open-access article under the CC-BY-SA license.

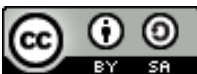


Jurnal Penelitian Ilmu Pendidikan, 14 (2), 2021 - 103

Apriani, Suwandi, Ariyani, \& Sari

\section{PENDAHULUAN}

Generasi bangsa yang berkualitas merupakan investasi peradaban suatu bangsa, begitu pula bagi Indonesia. Generasi muda Indonesia yang cerdas, berakhlak mulia dan berkepribadian Indonesia dapat diwujudkan melalui usaha pendidikan karakter secara sadar dan terencana (Santika, 2020). Pendidikan karakter merupakan usaha nyata guna mengajarkan peserta didik tentang nilai, budi pekerti, moral melalui berbagai pembiasaan dengan tujuan mengembangkan kemampuannya dalam memutuskan hal baik dan buruk, serta keteladanan dalam menyelesaikan masalah di masyarakat dikemudian hari. Pendidikan karakter ini berkaitan dengan penanaman dan penguatan nilai-nilai kehidupan baik dan universal. Kemudian, karakter itu sendiri tidak hanya berbicara mengenai kepribadian diri sendiri atau orang lain, melainkan bentuk kepribadian yang baik yang membuat diri sendiri atau orang lain saling memberikan kebaikan dan kebahagiaan (Apriani, Sari, \& Suwandi, 2017).

Pendidikan karakter wajib dilaksanakan secara berkesinambungan, baik di lingkungan keluarga, sekolah, maupun masyarakat. Upaya tersebut juga dilakukan dalam rangka menanggulangi dekadensi moral yang sedang dialami bangsa Indonesia pada saat ini, baik anak-anak, remaja, maupun orang dewasa. Dekadensi moral bangsa Indonesia ditunjukkan antara lain dari adanya 1000 kasus kekerasan yang ditemukan sepanjang tahun 2016, berbagai peristiwa intoleransi, radikalisme, terorisme, dan separatisme; pengguna narkoba sekitar 5,1 juta dan ada 15.000 orang meninggal setiap tahun; serta meningkatnya pornografi dan cyber crime yang ditunjukkan dengan adanya 1.111 kasus sepanjang tahun 2011-2015, dan krisis kepribadian bangsa (Budiman, 2017). Umumnya, guru membelajarkan karakter kepada peserta didik melalui keteladanan dan pembelajaran yang dilakukan di kelas. Namun, seluruh dunia saat ini sedang dilanda pandemi corona virus disease 19 (Covid-19), termasuk Indonesia. Pandemi Covid-19 tersebut berpengaruh pada semua sendi kehidupan, baik dari bidang ekonomi, sosial, politik, tidak terkecuali bidang pendidikan. Sebagai langkah awal antisipasi terhadap pandemi ini, pemerintah Indonesia mencanangkan kebijakan "Adaptasi Kebiasaan Baru" atau biasa disebut "New Normal" (Admin, 2020). Kebijakan "Adaptasi Kebiasaan Baru" (New Normal) didefinisikan sebagai tatanan, kebiasaan dan perilaku yang baru berbasis pada adaptasi untuk membudayakan perilaku hidup bersih dan sehat (Admin, 2020). Masyarakat diharapkan dapat memperhatikan dan melaksanakan kebijakan Adaptasi Kebiasaan Baru (New Normal) agar tetap aman dari terjangkitnya virus Covid-19. Kebijakan Adaptasi Kebiasaan Baru ini dilakukan pada seluruh bidang, tak terkecuali pada bidang pendidikan.

Bidang pendidikan, di mana menaungi peserta didik dari pendidikan formal maupun nonformal, harus beradaptasi secara cepat agar kegiatan pembelajaran tetap terlaksana di masa pandemi Covid-19 (Shaleh, 2020). Pemerintah melalui Surat Edaran Nomor 4 Tahun 2020 tentang Pelaksanaan Kebijakan Pendidikan selama Pandemi Covid-19, telah menyusun kebijakan-kebijakan terkait pelaksanaan pembelajaran selama masa pandemi. Hal ini disebabkan antara lain karena kegiatan pembelajaran tatap muka tidak dapat dilaksanakan seperti sebelumnya. Kegiatan pembelajaran dengan mengumpulkan sejumlah orang sangat dianjurkan untuk dihindari, bahkan ditiadakan dalam masa pandemi Covid-19. mengikuti kaidah ilmiah dengan baik dan benar.

Pemerintah Indonesia menganjurkan peserta didik untuk melakukan kegiatan belajar di rumah. Kebijakan pembelajaran di rumah tersebut dikenal dengan "Belajar dari Rumah" (BDR) dan dilakukan melalui pembelajaran jarak jauh dalam jaringan (daring) dan/atau luar jaringan (luring). Kebijakan BDR secara daring dianjurkan oleh pemerintah pusat maupun daerah (Rafsanjani, 2020). Pelaksanaan BDR tersebut berpedoman pada Surat Edaran Nomor 15 Tahun 2020 tentang Pedoman Penyelenggaraan Belajar dari Rumah dalam Masa Darurat Penyebaran Corona Virus Disease (Covid-19). Kegiatan pembelajaran BDR dilakukan guna memenuhi hak peserta didik, baik tingkat sekolah dasar, menengah, maupun perguruan tinggi untuk tetap mendapatkan layanan pendidikan walaupun sedang dalam kondisi darurat penyebaran Covid-19. Dan agar para peserta didik dan seluruh warga satuan pendidikan terhindar dari paparan Covid-19.

Pembelajaran daring pada dasarnya merupakan metode Pembelajaran Jarak Jauh (PJJ) dengan menggunakan bantuan perangkat elektronik seperti smartphone, tablet, laptop, perangkat komputer melalui beberapa portal dan aplikasi pembelajaran daring yang telah disebutkan di dalam lampiran SE Nomor 15 Tahun 2020. Berdasarkan edaran tersebut, kegiatan BDR dilaksanakan untuk memberikan pengalaman belajar yang bermakna bagi peserta didik, tanpa terbebani tuntutan kurikulum untuk 
kenaikan kelas ataupun kelulusan sekolah. Materi pembelajaran yang disampaikan guru bersifat inklusif dan disesuaikan dengan usia dan jenjang pendidikan peserta didik, juga dalam konteks budaya, karakter, serta jenis kekhususan yang dimiliki oleh peserta didik. Dengan tidak adanya tuntunan kurikulum yang harus dipenuhi untuk kenaikan kelas maupun kelulusan, pembelajaran pendidikan karakter selayaknya mendapatkan porsi lebih, khususnya di jenjang sekolah dasar. Penguatan karakter generasi muda Indonesia diperlukan agar generasi muda Indonesia memiliki keunggulan dalam persaingan global abad ke-21 (Hendarman et al, 2019). Hal tersebut juga merupakan salah satu upaya pemerintah Indonesia dalam menciptakan generasi emas Indonesia 2045, yakni melalui program Penguatan Pendidikan Karakter (PPK). PPK tersebut dilakukan tidak hanya dilakukan di sekolah atau kelas. Sekolah perlu melibatkan orang tua/wali dan masyarakat guna mendorong pelibatan publik. Dengan demikian, PPK dapat dilakukan guru dengan melibatkan orang tua/wali peserta didik ketika kegiatan BDR.

Pembelajaran daring di masa pandemi Covid-19 menjadi tantangan tersendiri, khususnya bagi guru dalam rangka mencapai hasil belajar peserta didik. Pendidik harus melakukan adaptasi dan inovasi dalam menyajikan kegiatan pembelajaran yang bermakna (Susiloningsih, 2020). Pelaksanaan pendidikan karakter ketika pandemi Covid-19 merupakan tantangan bagi guru sekolah dasar karena adanya keterbatasan pertemuan tatap muka. Padahal, penanaman dan penyisipan karakter sangat penting serta dapat dilakukan walau secara daring (Kusumadewi, Yustiana, \& Nasihah, 2020). Kondisi pandemi Covid-19 berpengaruh pada implementasi pendidikan karakter (Abdusshomad, 2020). Kemauan, kebiasaan, naluri, dan suara hati merupakan beberapa faktor yang mempengaruhi proses internalisasi karakter selama pandemi Covid-19. Selanjutnya, Mustikaningrum, Linda, Buamona, Cahyadi, \& Istiqomah, (2020) menambahkan bahwa pembelajaran pada masa pandemi Covid-19 dilakukan melalui pemberian tugas dengan cara membuka tautan yang diberikan oleh pendidik, kemudian peserta didik menceritakan hal-hal yang terkandung dalam tautan tersebut. Pendidikan karakter juga dilaksanakan secara daring. Oleh sebab itu, guru perlu memilih strategi/model yang tepat untuk menanamkan dan menguatkan karakter peserta didik dalam pembelajaran daring. Walaupun, kebijakan pemerintah dalam pendidikan lambat laun akan berubah menyesuaikan masa new normal dengan mengkombinasikan pembelajaran secara virtual dan tatap muka sebagai solusi yang terbaik.

Tugas guru dalam menanamkan nilai karakter peserta didik sejak usia dini pada masa new normal merupakan hal yang penting untuk dilaksanakan. Shaleh \& Miswar (2020), berpendapat pelaksanaan pendidikan moral bagi anak usia sekolah dasar pada masa new normal menjadi perhatian bagi semua pelaksana dan pemerhati pendidikan. Hal ini disebabkan konteks pembelajaran tidak hanya berpusat pada aspek kognitif atau pengetahuan saja, tetapi juga pada pembelajaran yang bermakna (mengandung internalisasi nilai moral) bagi anak usia sekolah dasar. Pada masa new normal, penyelenggaran pendidikan karakter yang biasanya pembiasaan-pembiasaan di sekolah, maka harus diubah secara online. Upaya pembentukan peserta didik supaya mempunyai karakter yang tangguh bukan sekadar tugas tambahan guru, melainkan tanggung jawab yang melekat pada perannya sebagai guru (Santika, 2020). Penguatan karakter berperan penting dalam mewujudkan generasi emas Indonesia 2045 yang bertaqwa, nasionalis, tangguh, mandiri, serta mampu bersaing secara global. Oleh karena itu, pendidikan karakter pada masa new normal wajib dilakukan oleh semua guru Sekolah Dasar (SD).

Berdasarkan pemaparan di atas, disimpulkan bahwa pencapaian tujuan pembelajaran baik ranah kognitif, afektif, dan psikomotorik dalam masa pandemi Covid-19 memerlukan upaya yang lebih. Guru SD dituntut untuk melakukan perencanaan dan pelaksanaan pembelajaran yang kreatif dan adaptif melalui pendekatan pembelajaran terefektif pada masa new normal karena pembelajaran pada masa ini tidak memungkinkan guru dan peserta didik untuk dapat melakukan tatap muka secara langsung (Hastuti, 2020). Salah satu alternatif pendekatan pembelajaran yang dapat dipilih guru guna mendukung program PPK di masa new normal, yaitu flipped classroom. Jumlah penyampaian materi pembelajaran secara tatap muka langsung antara guru dan peserta didik dalam pendekatan pembelajaran flipped classroom dikurangi atau diminimalisir. Pendekatan ini mengkombinasikan antara pembelajaran di dalam kelas dan di luar kelas dengan tujuan untuk mengoptimalkan kegiatan pembelajaran yang bermakna, sehingga tujuan pembelajaran tercapai (Hastuti, 2020). Munfaridah (2017) menambahkan bahwa flipped classroom adalah pendekatan pembelajaran yang menggunakan bantuan teknologi untuk membantu guru dalam menyampaikan materi pembelajaran kepada peserta didik. Guru dapat menggunakan bantuan media video untuk membantu peserta didik menemukan dan membentuk konsep materi pelajaran secara mandiri. Peserta didik awalnya diminta guru untuk 
menonton dan menyimak isi video pembelajaran di rumah. Kemudian, saat peserta didik belajar di kelas, peserta didik diberi kesempatan untuk mengerjakan tugas, latihan soal, proyek, ataupun diskusi materi dari video tersebut.

Kreatifitas dan inovasi guru dalam membangun dan memperkuat karakter peserta didik diharapkan dapat dimaksimalkan melalui pendekatan pembelajaran flipped classroom ini. Hal ini disebabkan flipped classrom berpeluang memberikan kemudahan bagi guru dalam menanamkan nilai-nilai moral yang mendukung dan membantu tercapainya tujuan program PPK, khususnya pada masa new normal Covid-19. Salah satu karakter yang biasa dikembangkan melalui pembelajaran daring ialah kemandirian. Karakter kemandirian merupakan salah satu dari lima nilai utama program PPK. Kemandirian sendiri dapat didefinisikan sebagai kesadaran diri untuk belajar mandiri dan tidak menggantungkan diri kepada orang lain. Pernyataan tersebut didukung oleh hasil penelitian sebelumnya yang menunjukkan bahwa karakter yang tepat saat pembelajaran daring adalah karakter mandiri, sebab peserta didik mampu mengerjakan tugasnya secara mandiri dan tidak bergantung pada orang lain (Kusumadewi et al., 2020). Penanaman karakter mandiri selama pembelajaran daring membutuhkan kerja sama antara guru dengan orang tua. Selain karakter kemandirian, karakter lainnya pun perlu dikembangkan dengan kerjasama antara guru, orang tua/wali, dan juga masyarakat. Berdasarkan permasalahan tersebut, penulis berusaha memberikan gagasan pendekatan dalam usaha penguatan pendidikan karakter bangsa pada masa new normal Covid-19 melalui flipped classroom. Tujuan dari penelitian, yaitu memaparkan tentang peran flipped classroom dalam membangun dan memperkuat karakter peserta didik sekolah dasar pada masa new normal Covid-19.

\section{METODE}

Jenis penelitian yang digunakan yaitu penelitian kepustakaan dengan pendekatan deskriptif kualitatif. Penelitian kepustakaan yaitu jenis penelitian yang berhubungan dengan data-data yang berasal dari buku, ensklopedia, kamus, jurnal, dokumen, hasil penelitian, majalah dan lain sebagainya (Harahap, 2014). Selanjutnya, penelitian kepustakaan tidak hanya mengumpulkan, membaca dan mencatat literatur. Penelitian kepustakaan memperhatikan langkah-langkah dalam meneliti, metode penelitian guna memperoleh dan mengumpulkan data, membaca dan mengolah data serta peralatan yang harus digunakan dalam penelitian tersebut, dengan tujuan mempermudah peneliti dalam mendapatkan data (Khatibah, 2011).

Sumber data penelitian adalah sumber data sekunder. Sumber data sekunder yaitu bahan pustaka yang ditulis dan dipublikasikan seorang penulis. Analisis data yang digunakan adalah analisis isi data informasi tertulis. Data dalam penelitian ini berupa hasil-hasil penelitian seperti buku-buku ilmiah, artikel ilmiah, laporan penelitian, dan sumber lain yang relevan (Sukmadinata, 2011). Sumber data sekunder yang digunakan berasal dari buku dan artikel ilmiah. Pemilihan sumber data sekunder yang digunakan mencakup kajian penguatan pendidikan karakter, pembelajaran daring, dan pendekatan flipped classroom pada masa new normal Covid-19. Sumber data sekunder berupa buku ilmiah memiliki batasan waktu dari tahun 2011 hingga 2019, sedangkan sumber data sekunder berupa artikel ilmiah yang memiliki batasan waktu dari tahun 2012 hingga 2020.

Langkah-langkah yang digunakan dalam penelitian ini meliputi tiga tahap, yaitu organize, synthesize, dan identify (Taylor, n.d.). Tahap pertama, penulis mengumpulkan berbagai artikel-artikel ilmiah yang memaparkan tentang penguatan pendidikan karakter, penguatan pendidikan karakter pada masa new normal Covid-19, dan pendekatan flipped classroom pada masa new normal Covid-19. Artikel-artikel ilmiah yang dikumpulkan di-review agar sesuai dengan permasalahan. Penulis melakukan pencarian ide dan simpulan dari beberapa artikel ilmiah melalui proses membaca abstrak, pendahuluan, metode, dan pembahasan. Tahap kedua, penulis menyatukan hasil organisasi artikelartikel ilmiah menjadi suatu ringkasan agar menjadi satu kesatuan yang utuh dan bermakna dengan mencari keterkaitan antar artikel ilmiah yang memaparkan tentang penguatan pendidikan karakter pada masa new normal Covid-19 melalui flipped classroom. Tahap ketiga, penulis mengidentifikasi ringkasan dalam artikel ilmiah untuk memperoleh tulisan yang menarik mencakup hasil dan pembahasan tentang penguatan pendidikan karakter pada masa new normal Covid-19 melalui flipped classroom. 
Jurnal Penelitian Ilmu Pendidikan, 14 (2), 2021 - 106

Apriani, Suwandi, Ariyani, \& Sari

\section{HASIL DAN PEMBAHASAN}

\section{Hasil}

\section{Penguatan Pendidikan Karakter}

Pendidikan karakter merupakan hal yang fundamental dalam kehidupan generasi bangsa Indonesia. Pendidikan karakter termasuk investasi peradaban guna membentuk generasi cerdas dan bermoral. Pendidikan karakter berhubungan dengan pengembangan nilai nilai moral peserta didik. Pendidikan karakter berlangsung terus menerus dalam waktu yang tidak ada batasan guna mewujudkan tujuan pendidikan nasional 2045. Pendidikan karakter merupakan program nasional guna membangun dan membina karakter generasi muda yang bermoral, karena pendidikan karakter memfokuskan pada nilai-nilai moral Pancasila. Program pendidikan karakter direncanakan dan dilaksanakan untuk menguatkan nilai-nilai moral yang mencakup aspek pengetahuan, perasaan, dan tindakan moral. Pelaksanaan PPK tidak bisa lepas dari keterlibatan serta kerjasama antara sekolah, keluarga, dan masyarakat. Menanam, membangun, dan memperkuat nilai-nilai karakter terhadap siswa dalam program PPK merupakan tujuan utama guna membenahi pelaksanaan pendidikan nasional yang lebih beradab. PPK dirasa sangat penting untuk dilaksanakan sejak usia dini dengan harapan membentuk pembelajar sepanjang hayat.

Penguatan Pendidikan Karakter (PPK) merupakan usaha sadar dan terencana dari pemerintah pusat untuk memperbaiki sistem pendidikan nasional. Perbaikan sistem pendidikan nasional juga dilakukan dengan menyempurnakan Kurikulum Tingkat Satuan Pendidikan (KTSP) menjadi kurikulum 2013. Kurikulum 2013 disempurnakan dengan perubahan standar isi dan penilaian berbasis pendidikan karakter melakui gerakan PPK. Penerapan gerakan PPK melalui penanaman dan pengembangan akhlak mulia peserta didik menggunakan prisip nilai-nilai moral universal, holistik, terintegrasi, dan selaras dengan perkembangan peserta didik. Penguatan pendidikan karakter relevan untuk mengatasi krisis moral yang sedang terjadi pada generasi penerus bangsa Indonesia. Penyimpangan nilai moral dilakukan semua kalangan dari tingkat anak-anak, remaja, hingga orang dewasa tanpa melihat status kasta, sosial, ekonomi, suku, ras, dan agama.

Penguatan pendidikan karakter bertujuan menyempurnakan sistem pendidikan nasional yang memposisikan peran karakter sebagai jiwa utama dalam penyelenggaraan pendidikan nasional, membangun dan membekali generasi emas Indonesia 2045 dalam menghadapi perubahan global dengan keterampilan abad 21, mengembalikan pendidikan karakter sebagai pondasi utama dalam pendidikan, memperkuat kapasitas ekosistem pendidikan dalam melaksanakan pendidikan karakter, membangun masyarakat sebagai sumber belajar, dan melestarikan kebudayaan bangsa Indonesia. Gerakan PPK bertujuan untuk membekali generasi muda dengan nilai-nilai moral pancasila yang menjadi fokus utama dalam pengembangan gerakan PPK yaitu religius, nasionalisme, integritas, kemandirian, dan kegotong royongan (Kemendikbud, 2017). Kelima nilai utama saling berhubungan, saling mendukung, melengkapi, dan berkolaborasi guna membentuk pribadi manusia utuh yang mengamalkan nilai-nilai Pancasila dalam kehidupan bermasyarakat.

Berdasarkan ulasan di atas, Gerakan PPK menempati kedudukan yang penting dan pokok untuk membenahi sistem pendidikan nasional yang bertujuan membentuk generasi emas 2045 yang beradab dengan jiwa Pancasila dalam kehidupan lokal, nasional, maupun global. Gerakan penguatan pendidikan karakter dalam KTSP maupun kurikulum 2013 wajib dilakukan secara konsisten dan komitmen tanpa kata henti dan batas waktu. Gerakan PPK di sekolah membutuhkan kerja sama dan keterlibatan dari lingkungan keluarga dan masyarakat guna mennginternalissikan kelima nilai utama dalam kehidupan secara kontekstual.

\section{Penguatan Pendidikan Karakter}

Karakter yang kuat dapat membentuk seseorang sebagai pelaku perubahan bagi dirinya sendiri maupun lingkungan sekitar. Karakter tersebut tercermin dari hasil olah pikir, olah raga, olah hati, serta olah rasa dan karsa seseorang atau sekelompok orang. Jadi dalam pendidikan karakter terdapat hubungan yang erat antara dimensi kognitif, afektif, maupun psikomotorik seseorang. Gerakan Penguatan Pendidikan Karakter (PPK) merupakan perwujudan dari Gerakan Revolusi Mental sekaligus bagian yang tidak terpisahan dari Nawacita. Gerakan PPK menempatkan pendidikan karakter sebagai 
dimensi inti pendidikan nasional. Gerakan PPK tersebut perlu diintegrasikan, diperdalam, diperluas, serta diselaraskan dengan berbagai program dan kegiatan pendidikan karakter yang dilaksanakan. Gerakan PPK memprioritaskan lima nilai utama karakter, dimana kelimanya yang saling berkaitan membentuk jejaring nilai. Kelima nilai karakter tersebut ialah karakter religius, nasionalis, kemandirian, gotong royong, dan integritas.

Implementasi Gerakan PPK dapat dilakukan dalam beberapa kegiatan, seperti kegiatan kelas, luar kelas di sekolah, dan luar sekolah seperti masyarakat/komunitas; kegiatan intrakurikuler, kokurikuler, dan ekstrakurikuler; dan pelibatan warga sekolah, keluarga, dan masyarakat. Gerakan PPK dapat dilakukan Pendalaman dan perluasan Gerakan PPK dapat dilakukan melalui penambahan dan pengintensifan kegiatan-kegiatan yang menitikberatkan pada pengembangan karakter siswa, penambahan dan pemanjangan kegiatan belajar siswa, serta pengaturan ulang waktu belajar siswa di sekolah atau luar sekolah. Sedangkan penyelarasan yang dilakukan berupa penyesuaian tugas pokok guru, Manajemen Berbasis Sekolah (MBS), dan fungsi Komite Sekolah dengan kebutuhan Gerakan PPK. Sinergitas antara sekolah, keluarga, dan masyarakat dalam Gerakan PPK diperlukan agar hasilnya maksimal dan optimal. Gerakan PPK di sekolah dapat dilaksanakan dengan berbasis struktur kurikulum yang sudah ada dan dimiliki, yakni: PPK berbasis kelas, PPK berbasis budaya sekolah, dan PPK berbasis masyarakat/komunitas (Kemendikbud, 2017). Adapun strategi pengimplementasian PPK di sekolah dapat dilakukan melalui kegiatan intrakurikuler, kegiatan kokurikuler, dan kegiatan ekstrakurikuler. Jadi, pelaksanaan pendidikan karakter pada peserta didik dapat dilakukan secara keseluruhann mencakup kegiatan pembelajaran dan luar pembelajaran.

Adanya pandemi Covid-19, maka pemerintah menghimbau masyarakat untuk melakukan physical distancing (menjaga jarak), stay at home, dan menghindari segala aktivitas yang melibatkan banyak orang sebagai upaya untuk menekan penyebaran Covid-19. Himbauan tersebut juga berlaku dalam pelaksanaan pembelajaran di sekolah. Kegiatan pembelajaran masih dapat dilakukan di sekolah dengan menerapkan protokol kesehatan yang ketat. Beberapa kebijakan terkait pelaksanaan pembelajaran selama pandemi Covid-19 diturunkan. Kebijakan awal, yaitu Surat Edaran bernomor 36962/MPK.A/HK/2020 tentang Pembelajaran secara Daring dan Bekerja dari Rumah dalam Rangka Pencegahan Penyebaran Covid-19 yang ditujukan untuk semua kepala dinas pendidikan dasar, menengah, hingga perguruan tinggi. Selanjutnya, Surat Edaran Mendikbud Nomor 4 Tahun 2020 tentang Pelaksanaan Pendidikan Dalam Masa Darurat Coronavirus Disease (Covid-19). Edaran tersebut diperkuat dengan Surat Edaran Nomor 15 Tahun 2020 tentang Pedoman Penyelenggaraan Belajar dari Rumah dalam Masa Darurat Penyebaran Covid-19 oleh Kemdikbud. Pedoman Belajar Dari Rumah (BDR) tersebut ditujukan kepada dinas pendidikan, kepala satuan pendidikan, pendidik, peserta didik, hingga orang tua/wali peserta didik.

"Belajar Dari Rumah/BDR" menjadi solusi alternatif pelaksanaan kegiatan pembelajaran di masa pandemi Covid-19. Hal tersebut merupakan salah satu upaya untuk memutus mata rantai Covid19 di sekolah. Selain itu, keselamatan dan kesehatan peserta didik, pendidik, kepala sekolah, dan seluruh warga satuan pendidikan merupakan pertimbangan utama dalam pelaksanaan kegiatan belajar mengajar di sekolah. Pelaksanaan BDR selama pandemi Covid-19 bertujuan untuk: memastikan pemenuhan hak peserta didik untuk mendapatkan layanan pendidikan selama darurat Covid-19; melindungi warga satuan pendidikan dari dampak negatif pandemi Covid-19; mencegah penyebaran dan penularan Covid-19 di satuan pendidikan; (SE Kemdikbud No. 15 Tahun 2020, 2020). BDR dilaksanakan dengan Pembelajaran Jarak Jauh (PJJ) yang dibagi ke dalam dua pendekatan, yaitu pembelajaran dalam jaringan (daring) dan pembelajaran luar jaringan (luring). Dalam pelaksanaan PJJ tersebut, sekolah dapat memilih pendekatan sesuai dengan ketersediaan dan kesiapan sarana dan prasarana (Kemdikbud, 2020). Jadi, sekolah dapat memilih untuk melaksanakan PJJ secara daring, luring atau kombinasi keduanya (blended learning).

Penyelenggaran pendidikan karakter pada masa pandemi Covid-19 harus diubah secara online. Pembelajaran tatap muka secara langsung antara guru dengan peserta didik sangat minim pada masa pandemi Covid-19 ini. Padahal metode role model (teladan) secara langsung oleh guru adalah salah satu upaya utama untuk transfer of values kepada peserta didik yaitu penanaman dan pengembangan nilainilai moral peserta didik. Hasil penelitian Susiloningsih (2020) menunjukkan bahwa penanaman nilai karakter pada masa new normal semaksimal mungkin dapat diusahakan dengan beberapa cara 
secara virtual seperti: pembelajaran kelas online, instruksi di grup WhatsApp, penggunaan aplikasi Google Meet/Zoom Meeting/Google Classroom.

Untuk menjembatani hal tersebut, maka dibutuhkan sinergitas yang lebih kuat antara guru, peserta didik, dan orang tua/wali, sehingga PPK tetap dapat berjalan dengan maksimal. PPK dapat diberikan kepada peserta didik melalui materi ajar berbentuk cerita (dapat dalam bentuk audio, visual, maupun audio-visual) yang mengandung muatan nilai moral saat BDR. Guru juga dapat memberikan penugasan BDR kepada siswa yaitu praktik langsung "suatu perbuatan baik atau bermoral" dalam kehidupan sehari-hari. Bahkan guru juga bisa memberikan tugas proyek kepada siswa tentang kasus sosial yang berhubungan nilai-nilai moral pada masa pandemi dengan menyelesaikan suatu kasus (problem solving). Tujuan utama pelaksanaan BDR ialah memberikan pengalaman belajar yang bermakna bagi peserta didik, pelaksanaan pembelajaran difokuskan pada pendidikan kecakapan hidup, serta materi pembelajarannya bersifat inklusif sesuai dengan usia, konteks budaya, karakter dan karakteristik perkembangan peserta didik. Pelaksanaan BDR membutuhkan dukungan dari orang tua/wali peserta didik agar dapat berjalan dengan lancar dan tercapai tujuannya. Oleh karena itu, guru perlu menjalin interaksi dan komunikasi yang positif dengan orang tua/wali peserta didik.

\section{Pendekatan Flipped Classroom pada Masa New Normal Covid-19}

Pelaksanan pembelajaran pada masa new normal Covid-19 memerlukan usaha dan kerja keras agar tujuan pembelajaran dapat tercapai, baik ranah kognitif, afektif, maupun psikomotorik. Guru dituntut untuk lebih kreatif dan adaptif dalam menentukan pendekatan pembelajaran yang efektif dalam pelaksanaan pembelajaran daring. Flipped Classroom merupakan salah satu alternatif pendekatan pembelajaran yang dinilai cukup efektif untuk diterapkan oleh pendidik pada masa new normal Covid19. Flipped classroom yaitu pembelajaran blended yang menggabungkan interaksi tatap muka dan virtual, mencakup pembelajaran sinkron dan asinkron. Pembelajaran sinkron terjadi secara langsung di kelas, peserta didik berinteraksi dengan pengajar dan teman sekelas, dan menerima umpan balik secara langsung. Sedangkan, pembelajaran asinkron bersifat lebih mandiri, menuntut peserta didik dapat memilih waktu belajar dan menyampaikan pertanyaan, pendapat atau pemahaman tentang materi (Hastuti, 2020). Jadi, model flipped classroom ini mempunyai konsep bahwa aktivitas pembelajaran yang biasanya diselesaikan di kelas "sekarang" dapat diselesaikan di rumah, dan aktivitas pembelajaran "yang biasanya dikerjakan di rumah" sekarang dapat diselesaikan di kelas (Bergmann, \& Sams, 2012). Oleh karena itu pendekatan flipped classroom merupakan pembelajaran ruang kelas yang fleksibel. Peserta didik dapat mengakses pembelajaran di mana saja dan kapan saja. Oleh kerena itu, pendekatan flipped classroom dapat digunakan sebagai solusi alternatif pelaksanaan kegiatan pembelajaran pada masa pandemi Covid-19.

Penggunaan flipped classroom pada masa pandemi covid-19 menuntut pendidik untuk merencanakan dan mempersiapkan empat aspek agar hasilnya maksimal yakni lingkungan yang fleksibel, budaya belajar, konten yang dibuat, dan pendidik yang profesional. Aspek lingkungan yang fleksibel mencakup persiapan waktu dan ruang belajar sesuai kebutuhan siswa, mempersiapkan penilaian yang tepat, dan menyediaakan berbagai metode/teknik bagi siswa untuk mempelajari dan menguasai materi. Aspek budaya belajar dengan memberikan kesempatan siswa untuk melakukan aktivitas pembelajaran secara mandiri dan membagi materi dalam beberapa tahapan agar siswa mudah memahami dengan cara yang berbeda. Aspek konten yang dibuat mengutamakan konsep intruksi langsung agar siswa dapat memahami materi dengan caranya sendiri, mengembangkan materi sesuai kebutuhan siswa, mempersiapkan beragam konten materi agar mudah diakses dan relevan untuk semua siswa. Aspek pendidik yang profesional menuntut pendidik untuk membimbing semua siswa secara individu maupun kelompok dan memberikan umpan balik, melakukan penilain formatif, dan berkolaborasi serta melakukan melakukan refleksi dengan pendidik yang lain (Hastuti, 2020).

Pendekatan flipped classroom mencakup menjadi tiga kegiatan penting yaitu sebelum kelas dimulai, saat kelas dimulai, dan setelah kelas berakhir. Sebelum kelas dimulai, peserta didik sudah mempelajari materi yang akan dibahas, kemampuan yang diharapkan dimiliki oleh peserta didik dalam tahap ini adalah mengingat dan mengerti tentang materi tersebut. Dengan demikian, peserta didik dapat mengaplikasikan dan menganalisis materi melalui berbagai kegiatan interaktif di dalam kelas pada saat kelas dimulai. Kemudian dilanjutkan mengevaluasi dan mengerjakan tugas berbasis proyek tertentu sebagai kegiatan setelah kelas berakhir (Hastuti, 2020). Kegiatan pembelajaran dari aspek mengingat 
hingga evaluasi melalui flipped classroom tersebut membutuhkan kerja sama dari guru, peserta didik, dan orang tua/wali. Sebagian guru dan orang tua/wali mungkin juga perlu kerja keras untuk selalu menasihati dan membimbing peserta didik agar kemampuan yang diharapkan tercapai.

Flipped classroom memiliki banyak manfaat dan dampak positif bagi perkembangan moral siswa seperti peserta didik lebih banyak tanggung jawab untuk pembelajaran. Karena banyaknya tanggung jawab untuk pembelajaran mereka sendiri tersebut, peserta didik dapat berlatih untuk mengembangkan keterampilan belajar individual yang lebih efektif. Kemudian, peserta didik juga harus mencari solusi dan menyelesaikan masalah secara mandiri ketika menghadapi suatu permasalahan dalam proses belajar. Kemandirian ini memberikan dampak dalam peningkatan kepercayaan diri peserta didik di kelas yang berdampak positif pada tingkat keterlibatan peserta didik yang lebih tinggi.

\section{Pembahasan}

Pelaksanaan pendidikan karakter dalam sistem pendidikan nasional berlangsung sepanjang hayat. Namun, konsep pendidikan karakter yang sudah dilaksanakan perlu dievaluasi dan diperdalam kontennya untuk menemukan suatu program yang tepat dan sesuai dengan abad 21. Apriani (2019) menjelaskan bahwa pendidikan karakter perlu diperdalam dalam sistem pendidikan nasional sehingga diperlukan program penguatan pendidikan karakter bangsa. Pendidikan karakter adalah poros pelaksanaan pendidikan dasar dan menengah di Indonesia. Penguatan Pendidikan Karakter (PPK) dikembangkan pemerintah pusat sebagai program pendidikan di sekolah dengan tujuan memperkuat moral peserta didik. Program PPK mencakup keselarasan dan keseimbangan antara moral knowing, moral feeling, dan moral acting. Kemampuan peserta didik dalam moral knowing, moral feeling, dan moral acting sesuai nilai-nilai Pancasila dapat dikembangkan melalui PPK. PPK bertujuan untuk memperkuat karakter melalui proses pembentukan, transformasi, transmisi, dan pengembangan potensi peserta didik dengan cara harmonisasi olah hati, olah rasa, olah pikir, dan olah raga sesuai falsafah hidup Pancasila (Hendarman et al, 2019). Trimantara (2020) menambahkan bahwa nilai karakter dalam Gerakan PPK ditempatkan sebagai poin terdalam pendidikan yang membudayakan dan memberadabkan para pelaku pendidikan.

PPK sebagai perwujudan dari Gerakan Nasional Revolusi Mental (GNRM), yakni berubahnya pola berfikir, bersikap dan berperilaku ke arah yang lebih baik melalui penanaman nilai utama (religius, nasionalis, mandiri, gotong royong, dan integritas) melalui sistem pendidikan nasional. Harapannya, seluruh peserta didik mengetahui, memahami, dan menerapkan kelima nilai utama tersebut pada setiap aspek kehidupannya, di manapun dan kapanpun peserta didik berada (Anshori, 2017). Hal tersebut menunjukkan bahwa gerakan PPK berperan besar untuk menguatkan nilai-nilai kehidupan baik aspek pengetahuan, perasaan, dan tindakan moral. Gerakan PPK akan membentuk kualitas pribadi yang cerdas, baik, dan bermanfaat bagi dirinya, orang lain, dan masyarakat luas yang mengutamakan nilainilai universal dalam keragaman (Apriani et al., 2017). Hendarman et al (2019), mengintegrasikan bahwa Gerakan PPK dapat dilakukan dalam beberapa bentuk, yaitu kegiatan kelas, luar kelas di sekolah, dan luar sekolah seperti masyarakat/komunitas; kegiatan intrakurikuler, kokurikuler, dan ekstrakurikuler; dan pelibatan warga sekolah, keluarga, dan masyarakat.

Berdasarkan Surat Edaran Kemdikbud Nomor 15 Tahun 2020 tentang "Pedoman Penyelenggaraan BDR dalam Masa Darurat Penyebaran Covid-19", maka pelaksanaan pembelajaran dalam masa new normal covid-19 ini dimungkinkan untuk melakukan pendekatan PJJ kombinasi, yaitu pendekatan daring maupun luring. Metode belajar kombinasi online (daring) dan offline (luring) dinilai lebih efektif untuk pelaksanaan pembelajaran BDR (Tuasikal, 2020). Salah satu model yang mengkombinasikan antara pembelajaran daring dan luring adalah model flipped classroom. Flipped classroom diperkenalkan oleh Jonathan Bergmann dan Aaron Sams untuk siswa yang mengalami ketinggalan materi/kelas dengan menggunakan rekaman video langsung dan perangkat lunak untuk merekam ceramah, demonstrasi dan slide presentasi untuk dilihat dan dibaca siswa (Hamdan, McKnight, McKnight, \& Arfstorm, 2013).

Flipped classroom merupakan inovasi pembelajaran yang menuntut peserta didik mempelajari materi pembelajaran secara mandiri, baik di luar kelas atau rumah, lalu melakukan diskusi bersama di kelas (Ahmed \& Indurkhya, 2020; Bhat, Raju, Bhat \& D'Souza, 2020). Flipped classroom membuat perubahan dalam urutan proses pembelajaran tradisional. Peserta didik belajar memahami konsep di 
rumah melalui bahan pembelajaran daring, sedangkan tatap muka di kelas digunakan untuk diskusi, tanya jawab, praktik atau mengerjakan proyek yang di bawah bimbingan guru guna memperdalam pemahaman tentang materi yang sudah dipelajari di rumah. Strayer, Hart, \& Bleiler-Baxtern (2016) menjelaskan bahwa tiga prinsip yang diterapkan dalam pembelajaran flipped classroom yaitu: (1) tugas luar kelas guna mendorong peserta didik melakukan proses refleksi dan memperoleh tanggapan dari teman-temannya, (2) tugas dalam kelas guna membangun pengetahuan baru sebagai bagian dari komunitas belajar di kelas, serta (3) menghubungkan antara tugas luar kelas dan dalam kelas dengan pendekatan instruksi dari pendidik. Selanjutnya, Baker (2016) menambahkan bahwa ada empat tahapan kegiatan belajar dengan flipped classroom, yaitu klarifikasi: peserta didik diajak untuk memulai diskusi dengan cara mengajukan pertanyaan untuk siswa yang mendapatkan tugas mempelajari materi sebelumnya, ekspansi: peserta didik diajak untuk menyusun bahan materi berdasarkan hasil pengalamannya atau sumber bacaan lain. Tahap kedua ini menjadikan peserta didik berperan sebagai kontributor pengetahuan serta menempatkan materi tersebut ke dalam pengalaman pribadinya, aplikasi: peserta didik dapat memahami dan menerapkan konsep dalam kehidupan nyata (kontekstual), serta latihan: pelibatan sekelompok siswa untuk berkolaborasi, misalnya menyelesaikan sebuah kasus, mengerjakan suatu proyek, atau problem solving.

Flipped classroom memiliki banyak manfaat seperti peserta didik lebih optimis dan terbuka terhadap pengetahuan baru, lebih aktif, lebih mandiri dan kreatif, serta lebih kritis dalam menyelesaikan permasalahan atau kasus (McLaughlin et.al., 2014). Flipped Classroom mampu meningkatkan kemandirian belajar siswa sehingga hasil belajar siswa meningkat. (Chandra \& Nugroho, 2017). Data yang telah dipaparkan di atas menunjukkan bahwa flipped classroom berperan penting untuk menguatkan karakter siswa melalui tugas dalam kelas dan tugas luar kelas dengan memaksimalkan kegiatan klarifikasi, ekspansi, aplikasi, dan latihan. Selanjutnya, peran flipped classroom dalam penguatan penddidikan karakter dibuktikan dengan hasil penelitian antara pembelajaran flipped classroom dan ceramah dengan nilai signifikansi $\mathrm{p}=0,003$, jadi flipped classroom unggul dalam pencapaian prestasi belajar dan upaya peningkatan karakter (Sudarmika, Santyasa, \& Divayana, 2020). Salah satu karakter yang dapat meningkat melalui pendekatan flipped classroom yaitu karakter kemandirian. Hasil penelitian dari Kim, Park, \& Joo (2014) menunjukkan bahwa pendekatan flipped classroom mampu meningkatkan kemampuan belajar mandiri lebih dari pembelajaran pada umumnya dan metode tradisional. Hal tersebut didukung dengan pernyataan Mirlanda, Nindiasari, \& Syamsuri (2019), yakni flipped classroom merupakan salah satu model pembelajaran yang dapat digunakan dalam upaya meningkatkan kemandirian belajar siswa. Berdasarkan beberapa pendapat tersebut menunjukkan bahwa pendekatan flipped classroom mendukung dalam penguatan pendidikan karakter peserta didik, yakni nilai kemandirian peserta didik dalam proses pembelajaran, baik pembelajaran secara virtual maupun tatap muka.

Melalui pendekatan flipped classroom guru lebih kreatif dan inovatif dalam memanfaatkan model tersebut guna membangun dan memperkuat karakter siswa. Flipped classrom memberikan peluang besar dalam penanaman nilai-nilai moral yang mendukung dan membantu tercapainya tujuan program penguatan pendidikan karakter terutama pada masa new normal Covid-19 dengan meningkatkan karakter kemandirian. Senada dengan hasil penelitian Chandra \& Nugroho (2017) bahwa flipped classroom mampu meningkatkan kemandirian belajar siswa sehingga hasil belajar siswa meningkat. Karakter kemandirian yaitu kesadaran diri untuk belajar mandiri serta tidak menggantungkan diri pada orang lain. Hendarman et al (2019) dalam sebuah tulisannya menyatakan bahwa nilai karakter "mandiri" didefinisikan sebagai "sikap dan perilaku tidak bergantung pada orang lain dan mempergunakan segala tenaga, pikiran, waktu untuk merealisasikan harapan, mimpi dan citacita". Nilai karakter "mandiri" tersebut mempunyai beberapa subindikator, antara lain etos kerja (kerja keras), tangguh tahan banting, daya juang, profesional, kreatif, keberanian, dan menjadi pembelajar sepanjang hayat. Karakter "mandiri" diperlukan peserta didik usia sekolah dasar untuk dapat menyiapkan dirinya sebagai warga masyarakat, warga negara, dan warga dunia yang baik nantinya. Kemandirian belajar ini juga berarti sebagai bentuk kesiapan individu untuk belajar dengan inisiatif sendiri, tanpa bantuan pihak lain, baik orang tua, keluarga, atau guru guna menentukan tujuan, metode dan evaluasi hasil belajar.

Berdasarkan ulasan di atas, disimpulkan bahwa Gerakan PPK melalui pendekatan flipped classroom sangat membantu pendidik dalam membangun dan menguatkan karakter peserta didik pada 
masa new normal Covid-19. Flipped classroom memberikan peluang besar dalam penanaman nilainilai moral yang mendukung dan membantu tercapainya tujuan program penguatan pendidikan karakter terutama pada masa new normal Covid-19. Salah satu nilai utama PPK yang dapat berkembang dan meningkat melalui pendekatan flipped classroom yaitu karakter kemandirian. Pelaksanaan PPK dalam pembelajaran di kelas melalui flipped classroom, guru dapat menggunakan beberapa metode dan strategi pembelajaran. Metode dan strategi pembelajaran yang digunakan guru secara tidak langsung dapat membantu menanam dan memperkuat karakter peserta didik. Dengan demikian, metode pembelajaran yang dipilih guru tersebut harus dapat membantu guru dalam memberikan pengetahuan dan keterampilan yang dibutuhkan oleh peserta didik.

\section{PENUTUP}

Penyelenggaran pendidikan karakter pada masa new normal Covid-19 yang biasa diajarkan melalui metode teladan dan pembiasaan secara langsung di sekolah, maka harus diubah secara daring. Pembelajaran tatap muka secara langsung antara guru dengan peserta didik sangat minim dalam masa pandemi Covid-19. Namun, pelaksanaan pendidikan karakter pada masa new normal Covid-19 harus dilakukan semaksimal mungkin dengan berbagai cara baik virtual maupun tatap muka. Penguatan nilai karakter secara virtual ini dapat dilakukan melalui media grup Whatsapp, penggunaan aplikasi Google Meet dan Zoom Meeting dengan dukungan dan kerjasama antara guru-orang tua/wali peserta didik. Dengan demikian, pendekatan flipped classroom mendukung dan membantu tercapainya tujuan program PPK pada masa new normal Covid-19 melalui pembelajaran virtual dan tatap muka dengan membimbing dan mengarahkan anak untuk memiliki karakter mandiri yaitu kesadaran diri untuk belajar mandiri dan tidak menggantungkan diri kepada orang lain. Karakter kemandirian merupakan salah satu bagian dari lima nilai karakter utama dalam program Penguatan Pendidikan Karakter (PPK). Rekomendasi untuk langkah selanjutnya bagi pendidik dalam menghadapi masa new normal covid-19 dalam program penguatan pendidikan karakter dengan menerapkan pendekatan flipped classrom dalam pembelajaran baik tematik maupun bidang studi dengan memaksimalkan sumber belajar yang ada dan mendukung serta kerja sama dengan lingkungan keluarga terutama orang tua peserta didik agar pendekatan tersebut efektif dan efisien dalam memperkuat karakter peserta didik SD.

\section{DAFTAR PUSTAKA}

Abdusshomad, A. (2020). Pengaruh covid-19 terhadap penerapan pendidikan karakter dan pendidikan Islam. QALAMUNA: Jurnal Pendidikan, Sosial, dan Agama, 12(2), 107-115. Doi:10.37680/qalamuna.v12i2.407.

Admin. (2020). Materi edukasi masyarakat umum: Adaptasi kebiasaan baru menuju masyarakat produktif dan aman covid-19. Diakses dari https://covid19.go.id/edukasi/masyarakatumum/adaptasi-kebiasaan-baru-menuju-masyarakat-produktif-dan-aman-covid-19, pada 5 Agustus 2021, pukul 13.59.

Ahmed, M. M. H., \& Indurkhya, B. (2020). Investigating cognitive holding power and equity in the flipped classroom, 6(e04672), 1-9. Doi: https://doi.org/10.1016/j.heliyon.2020.e04672.

Anshori, I. (2017). Penguatan pendidikan karakter di madrasah. Halaqa: Islamic Education Journal, 1(2), 63-74. doi:10.21070/halaqa.v1i2.1243.

Apriani, A.N. (2019). Living values education program: penguatan pendidikan karakter dalam pembelajaran tematik. Yogyakarta: K-Media.

Apriani, A.N., Sari, I. P., \& Suwandi, I. K. (2017). Pengaruh living values education program (lvep) terhadap penanaman karakter nasionalisme siswa sd dalam pembelajaran tematik. Taman Cendekia: Jurnal Pendidikan Ke-SD-An, 1(2), 102-112. Doi:10.30738/tc.v1i2.1947.

Baker, J.W. (2016). The origins of "the classroom flip". Paper presented at the The 1st Annual Higher Education Flipped Learning Conference, Greeley, Colorado. Retrieved from https://digscholarship.unco.edu/cgi/viewcontent.cgi?article=1058\&context=heflc\#pag\%0Ae= $21 \% 0 \mathrm{~A}$, at October 23, 2020, 06.19. 
Bergmann, J., \& Sams, A. (2012). Flipped your classroom: reach every student in every class every day. Retrieved from http://www.ascd.org/Publications/Books/Overview/Flip-YourClassroom.aspx.

Bhat, S., Raju, R., Bhat, S. \& D'Souza, R. (2020). Redefining quality in engineering education through the flipped classroom model. Procedia Computer Science, 172, 906-914. Doi: https://doi.org/10.1016/j.procs.2020.05.131.

Budiman. (2017). Infografis: gerakan penguatan pendidikan karakter (ppk). Retrieved from cerdasberkarakter.kemdikbud.go.id/content/download/44, diakses pada 23 Oktober 2020, pukul 06.19.

Chandra, F. H., \& Nugroho, Y. W. (2017). Implementasi flipped classroom dengan video tutorial pada pembelajaran fotografi komersial. Desain Komunikasi Visual, Manajemen Desain dan Periklanan (Demandia), 2(1), 20-36. doi:10.25124/demandia.v2i01.772.

Mustikaningrum, G., Linda, P., Buamona, S.A.M.U., Cahyadi, E., \& Istiqomah, W. (2020). Implementasi pendidikan karakter terintegrasi kurikulum dan metode pembelajaran pada masa pandemi covid-19. Jurnal Pendidikan Dasar Islam, 7(2), 154-164. doi:10.24252/10.24252/auladuna.v7i2a5.2020.

Hamdan, N., McKnight, P., McKnight, K., \& Arfstorm, K. M. (2013). A review of flipped learning. flipped learning network. Retrieved from https://flippedlearning.org/wpcontent/uploads/2016/07/LitReview_FlippedLearning.pdf, diakses pada 25 Oktober, 2020, pukul 07.19.

Harahap, N. (2014). Penelitian kepustakaan. Jurnal Iqra', 8(1), 68-73. Http://jurnal.uinsu.ac.id/index.php/iqra/article/download/65/245.

Hastuti, W. D. (2020). Membangun motivasi dan kemandirian peserta didik berkebutuhan khusus melalui flipped classroom di masa new normal covid-19. Paper presented at the Webinar Magister Pendidikan Nonformal Pascasarjana Universitas Negeri Gorontalo, Gorontalo. Retrieved from https://ejurnal.pps.ung.ac.id/index.php/PSI/article/view/367/328, 8 September 2020, pukul 13.01.

Hendarman et al. (2019). Konsep dan pedoman penguatan pendidikan karakter tingkat sekolah dasar dan sekolah menengah pertama. Jakarta: Tim PPK Kemendikbud.

Kemdikbud. (2020). Kemendikbud terbitkan pedoman penyelenggaraan belajar dari rumah. Retrieved from https://www.kemdikbud.go.id/main/blog/2020/05/kemendikbud-terbitkan-pedomanpenyelenggaraan-belajar-dari-rumah, pada 18 November 2020, pukul 11. 41.

Kemendikbud. (2017). Kajian dan pedoman penguatan pendidikan karakter (ppk). Diakses dari http://repositori.kemdikbud.go.id/10119/, pada 18 November 2020, pukul 14. 41

Khatibah, K. (2011). Penelitian kepustakaan. Iqra': Jurnal Perpustakaan dan Informasi, 5(1), 36-39. Http://repository.uinsu.ac.id/640/.

Kim, S. H., Park, N. H., \& Joo, K. H. (2014). Effects of flipped classroom based on smart learning on self-directed and collaborative learning. International Journal of Control and Automation, 7(12), 69-80. Doi:10.14257/ijca.2014.7.12.07.

Kusumadewi, R. F., Yustiana, S., \& Nasihah, K. (2020). Menumbuhkan kemandirian siswa selama pembelajaran daring sebagai dampak covid-19 di sd. JRPD (Jurnal Riset Pendidikan Dasar), 1(1), 7-13. Doi: 10.30595/.v1i1.7927.

McLaughlin, J. E., Roth, M. T., Glatt, D. M., Gharkholonarehe, N., Davidson, C. A., Griffi L. M., \& Mumper, R. J. (2014). The flipped classroom: A course redesign to foster learning and engagement in a health professions school. Academic Medicine, 89(2), 236-243. Doi: 10.1097/ACM.0000000000000086.

Mirlanda, E. P., Nindiasari, H., \& Syamsuri, S. (2019). Pengaruh pembelajaran flipped classroom terhadap kemandirian belajar siswa ditinjau dari gaya kognitif siswa. Symmetry: Pasundan Journal of Research in Mathematics Learning and Education. Doi:10.23969/symmetry.v3i2.1251.

Munfaridah. (2017). Penerapan model pembelajaran flipped classroom untuk melatih kemandirian belajar peserta didik dalam pembelajaran matematika. Universitas Islam Negeri Sunan Ampel Surabaya. Retrieved from http://digilib.uinsby.ac.id/21340/.

Rafsanjani, A. I. (2020, July 27). Kebijakan pendidikan di era new normal. Doi:10.31219/osf.io/29v6a. 
Santika, I. W. E. (2020). Pendidikan karakter pada pembelajaran daring. Indonesian Values and Character Education Journal, 3(1), 8-19. Doi:10.23887/ivcej.v3i1.27830.

Shaleh, A. M. (2020). Problematika kebijakan pendidikan di tengah pandemi dan dampaknya terhadap proses pembelajaran di Indonesia. Doi:10.31219/osf.io/pg8ef.

Shaleh, A. M. \& Miswar. (2020). Urgensitas pendidikan akhlak bagi anak usia dasar (Studi era darurat covid 19). Tazkiya, IX(2), 92-107. Retrieved from http://jurnaltarbiyah.uinsu.ac.id/index.php/tazkiya/article/view/836/632.

Strayer, J. F., Hart, J. B., \& Bleiler-Baxter, S. K. (2016). Flipped classroom. the Mathematics Teacher, 109(9), 662-668. Doi:10.5152/tcb.2015.064.

Sudarmika, P., Santyasa, I. W., \& Divayana, D. G. H. (2020). Comparison between group discussion flipped classroom and lecture on student achievement and student characters. International Journal of Instruction, 13(3), 171-186.

Sukmadinata. (2011). Metode penelitian. Bandung: Remaja Rosda Karya.

Susiloningsih, W. (2020). Pendidikan karakter sekolah dasar di era new normal. INVENITA, 4(2), 199205. Doi:10.36456/inventa.4.2.a2731.

Taylor, D. (n.d.). The literature review: a few tips on conducting it. Retrieved from https://www.coursehero.com/file/69653890/The-Literature-Review-A-Few-Tips-OnConddocx/.

Trimantara, H. (2020). Urgensi penguatan pendidikan karakter siswa sekolah dasar pada era revolusi industri 4.0. Paper presented at the Seminar Nasional STKIP PGRI Bandar Lampung, Bandar Lampung. $\quad$ Retrieved from http://stkippgribl.ac.id/proceeding/index.php/semnas/article/view/76, February 6, 2020, pukul 13.14 .

Tuasikal. (2020). Kombinasi belajar online-offline dinilai lebih efektif untuk tahun ajaran baru. Retrieved from https://www.voaindonesia.com/a/kombinasi-belajar-online-offline-dinilailebih-efektif-untuk-tahun-ajaran-baru/5466714.html, 18 November 2020, pukul 21.30. 